УДК 657.012.12

JEL Classification: M11

I. T. РАЙКОВСЬКА

кандидат економічних наук,

дочент кафедри обліку і оподаткування

Київський кооперативний інститут бізнесу і права

\title{
Стратегічний аналіз в системі довгострокового управління підприємством
}

В статті проведена систематизація поглядів науковиів стосовно місия стратегічного аналізу в системі управління підприсмством, визначено його завдання на сучасному етапі розвитку економічних відносин. Встановлено прямий та зворотний зв 'язок стратегічного аналізу з функціями управління та запропоновано розмежсування об 'сктів, предмету, завдань і суб 'сктів стратегічного аналізу за трьома формами прояву як галузі наукових знань, навчальної дисципліни та практичної діяльності.

Ключові слова: стратегічний аналіз, стратегічне управління, зовніинє середовище, внутрішнє середовище, стратегічні ріщення.

Постановка проблемш. Становлення ринкової економіки в Україні, виникнення і розвиток міжнародних і фінансових зв 'язків зумовили перетворення в сфері господарювання. Для ефективного здійснення своєї господарської діяльності підприємствам слід оперативно реагувати на будь-які зміни факторів зовнішнњого та внутрішнього середовища. Такі дії вимагають проведення стратегічного аналізу, оскільки він як основна складова внутрішнього економічного механізму підприємства має великий вплив на результативність підприємницької діяльності. У свою чергу, аналітична робота, яка використовує різноманітні методики аналізу, повинна служити основою для організації та прийняття управлінсыких рішень для забезпеченні стратегії розвитку підприємства.

На сучасному етапі не всі аспекти цієї проблеми з'ясовані. Важливим стає визначення функціональної ролі стратегічного аналізу в системі управління суб'єктом господарювання через у досконалення підходів до організації та методики його здійснення. Розробка організаційно-методичного механізму сприятиме об' єктивнішій оцінці життєдіяльності підприємств, розробці стратегії розвитку підприємства як в інтересах самого суспільства, так і держави в цілому. Необхідність вирішення зазначених проблем та їх вплив на розвиток економіки підприємства і суспільства в цілому обумовлює актуальність обраної теми дослідження.

Аналіз останніх досліджень і публікацій. Питання сутності стратегічного аналізу, його місця в системі довгострокового управління розглядали в своїх працях вітчизняні вчені, серед яких: Т.Г. Бурденюк, А.С. Гакман, Т.В. Головко, С.М. Жукевич, М.І. Ковальчук, Р.О. Костирко, І.С. Левик, В.В. Пастухова, І.М. Парасій-Вергуненко. П.Р. Пуцентейло, К.І. Редченко, І.В. Саух та ін. Організаційно-методичні засади стратегічного аналізу базуються на теорії менеджменту і розглядаються в працях відомих вчених - I. Ансоффа, К. Друрі, М. Десмонда, Б. Карлофа, Р. Келлі, М.Х. Мескона, М. Мінцберга, А.А. Томпсона, Д. Хана, Р. Холла. Проте в сучасних умовах висвітлення місця стратегічного аналізу в управлінні суб'єктом господарювання 3 урахуванням трансформаційних процесів економіки країни потребує додаткових досліджень, що обумовлено зміною сутнісного наповнення стратегічного аналізу і пов'язане із впливом факторів зовнішнього середовища.

Метою дослідження є розкриття ролі стратегічного аналізу в системі управління підприємством із паралельним визначенням зміни його змістовного наповнення, завдань та суб єктів в контексті розвитку суспільно-економічних відносин.

Виклад основного матеріалу. Перехід економіки до ринкових відносин спричинив ускладнення в діяльності кожного підприємства, якому важко прилаштуватися до стрімкого розвитку, сучасних технологій на ринку. На даний час в Україні діють підприємства різних організаційних форм і усіх форм власності, формування власної

(C) Н. Й. Радіонова, 2017 
стратегії для яких $\epsilon$ абеткою бізнесу і запорукою успіху. Тому неминуче мають і будуть відбуватися якісні зміни в управлінні підприємствами шляхом зорієнтованої на майбутнє стратегії.

В Україні теорія і практика стратегічного управління ще не зайняли належного рівня. Вітчизняним підприємствам важко застосувати стратегічне управління через складні умови господарювання, брак коштів для впровадження інноваційних процесів, недосконалу конкурентну боротьбу.

На сучасному етапі, нестабільність в політичному середовищі України значно впливає й на економічну політику суб'єкта господарювання. 3 однієї точки зору можна розглянути, що стратегічне управління, яке зорієнтоване на майбутнє, не можливо спрогнозувати наперед. Проте, на нашу думку, потрібно приділити ще більш значну увагу стратегічному управлінню підприємства з врахуванням не лише внутрішнього, але й значного зовнішнього впливу на суб'єкт господарювання. Адже, ефективність фінансової діяльності підприємств, у першу чергу, залежить від розробленої стратегії управління.

Зазначимо, що проблема економічної ефективності досягнення стратегічних цілей досліджувалася раніше і знаходила своє роз'яснення у період адміністративнокомандної моделі управління народним господарством. На рівні окремої галузі й підприємства проблема економічної ефективності з'являлася лише тоді, коли треба було оцінити перевагу того чи іншого варіанта технічного або організаційного рішення. Стратегічні цілі спускалися згори вниз у вигляді плану-закону, тому й не виникало потреби оцінювати переваги досягнення тих чи інших стратегічних цілей - вони були наперед визначені органами управління галузі. В умовах ринку застосування такого підходу втрачає будь-який сенс, оскільки підприємства керуються інтересами виживання.

Важливою особливістю $є$ і те, що досі існує інерція командної системи, згідно 3 якою підприємства зберегли звичку орієнтуватися на вищі керівні структури й органи влади, а власної ініціативи не виявляють.

В даному контексті стратегічний аналіз як функція стратегічного управління повинен підготувати множину альтернатив для прийняття рішення. Це майже завжди проблематично, оскільки в умовах невизначеності вибір альтернатив та їх належне аналітичне обгрунтування $є$ дуже складною процедурою.

Стратегічний аналіз займає суттєве місце в забезпеченні виконання найважливішої вимоги до управлінських рішень - наукового обгрунтування варіантів таких рішень, які б забезпечили досягнення максимальних довгострокових економічних результатів за мінімальних витрат ресурсів. 3 позиції Б.Г. Літвак, "Ефективне управлінське рішення, як правило, є поєднанням професіоналізму менеджера і його мистецтва керівника, оскільки, як справедливо вважають провідні спеціалісти у галузі прийняття управлінських рішень, прийняття рішень є одночасно і наукою, і мистецтвом" $[2$, c. 47]. Зазначимо, що “... Управлінські рішення на підприємстві залежать від мети його діяльності. Тому ефективність управлінських рішень залежить від ступеня досягнення поставлених завдань [3, с. 218].

Отже, визначимо, чим повинен виступати стратегічний аналіз на підприємстві. По-перше, як елемент системи управління, він слугує основою виявлення недоліків і резервів у господарській діяльності, підвищення ефективності використання економічних ресурсів, пошук нових резервів зменшення собівартості та збільшення обсягів виробництва, нарощування економічного потенціалу та вартості бізнесу. Подруге, як інформаційне забезпечення, він повинен охоплювати результати дій всіх інших функцій управління, базуватися на фактах їх прояву, переробляти та видавати нову інформацію про стан діяльності підприємства та його місце у зовнішньому середовищі, а також сприяти роботі систем управління і контролю.

Однак стратегічний аналіз в системі управління не виконує свою роль автономно, а взаємопов' язаний з іншими функціями менеджменту, впливає на розвиток і удосконалення їх. Виходячи з того, що в системі ринкових відносин функції системи управління наповнюються новим змістом, обгрунтовано взаємозв'язок стратегічного аналізу з ними (табл. 1). 
Зв'язок стратегічного аналізу з функціями управління

\begin{tabular}{|c|c|c|}
\hline $\begin{array}{c}\text { Функція } \\
\text { управління }\end{array}$ & Прямий зв'язок & Зворотний зв'язок \\
\hline $\begin{array}{l}\text { Планування } \\
\text { Стратегічний } \\
\text { аналіз }\end{array}$ & $\begin{array}{l}\text { За допомогою планування виз- } \\
\text { начаються напрям і зміст діяль- } \\
\text { ності підприємства, прогнози } \\
\text { можливих напрямів його розвит- } \\
\text { ку та стратегічні плани, чітке } \\
\text { встановлення яких впливає } \\
\text { на проведення та результати } \\
\text { стратегічного аналізу }\end{array}$ & $\begin{array}{l}\text { Планування не може здійсню- } \\
\text { ватися без проведення аналізу } \\
\text { зовнішнього середовища. Зокрема, } \\
\text { підприємство повинне визначити, } \\
\text { яких реальних результатів воно } \\
\text { може домогтися, оцінити свої } \\
\text { сильні і слабкі сторони, а також } \\
\text { стан зовнішнього середовища } \\
\text { (економічні умови в даній країні, } \\
\text { урядові акти, позиції профспілок, } \\
\text { дії конкуру ючих організацій, } \\
\text { переваги споживачів, суспільні } \\
\text { погляди, розвиток технологій) }\end{array}$ \\
\hline $\begin{array}{l}\text { Організація } \\
\text { Стратегічний } \\
\text { аналіз }\end{array}$ & $\begin{array}{l}\text { Організаційна структура як } \\
\text { прояв організації на підприємстві } \\
\text { постійно змінюється під впливом } \\
\text { зовнішніх і внутрішніх факторів. } \\
\text { Постійним єаналіз та оцінка діючих } \\
\text { організаційних структур з метою } \\
\text { іхх удосконалення, враховуючи } \\
\text { мінливе зовнішнє середовище }\end{array}$ & $\begin{array}{l}\text { Результати стратегічного аналізу } \\
\text { визначають порядок організації } \\
\text { діяль ності підпри ємства в } \\
\text { майбутньому }\end{array}$ \\
\hline $\begin{array}{l}\text { Мотивація } \\
\text { Стратегічний } \\
\text { аналіз }\end{array}$ & $\begin{array}{l}\text { При застосуванні мотиваційних } \\
\text { засобів слід чітко проаналізувати, } \\
\text { чи доцільні вони для підвищення } \\
\text { ефективності праці та всього } \\
\text { виробничого процесу в цілому }\end{array}$ & $\begin{array}{l}\text { Сформована стратегія розвитку } \\
\text { підпрнємства відображає майбут- } \\
\text { ні перспективи діяльності та } \\
\text { спонукають працівників до } \\
\text { підвищення продуктивності праці }\end{array}$ \\
\hline $\begin{array}{l}\text { Контроль } \\
\text { Стратегічний } \\
\text { аналіз }\end{array}$ & $\begin{array}{l}\text { Контроль дозволяє управлінському } \\
\text { персоналу стежити за ходом } \\
\text { виконання стратегічних управ- } \\
\text { лінських рішень }\end{array}$ & $\begin{array}{l}\text { Здійснення контролю неможливе } \\
\text { без стратегічного аналізу викорис- } \\
\text { тан ня економічн их ресу рсів } \\
\text { підприємства за звітний період }\end{array}$ \\
\hline $\begin{array}{l}\text { Координація та } \\
\text { регулювання } \\
\text { Стратегічний } \\
\text { аналіз }\end{array}$ & $\begin{array}{l}\text { Координація або регулювання } \\
\text { робіт в тій чи іншій мірі перед- } \\
\text { бачає використання методів } \\
\text { стратегічного аналізу, оскільки } \\
\text { визначає узгодженість у часі та } \\
\text { просторі дій органів управління } \\
\text { та посадових осіб, а також між } \\
\text { системою в цілому та зовнішнім } \\
\text { середовищем }\end{array}$ & $\begin{array}{l}\text { Чітко організована стратегічна } \\
\text { аналітична робота є одним } \\
\text { основним факторів, який впли- } \\
\text { ває на ефективне виконанн } \\
\text { поставлених завдань такої фунції } \\
\text { управління як координація }\end{array}$ \\
\hline
\end{tabular}

Джерело: побудовано автором

Таким чином, стратегічний аналіз є рушійним фактором в системі управління задля розробки стратегії розвитку підприємства, дієвим засобом виявлення внутрішньогосподарських та зовнішніх резервів, основою розробки науково обгрунтованих планів та стратегічних управлінських рішень. Крім того, стратегічне управління вимагає знань про стратегічну позицію підприємства на ринку та особливості реалізації стратегії. Це пов'язано з тим, що зміни обставин та їх комбінацій як всередині підприємства, так і поза ним потребують відповідних коригувань стратегії. Стратегічний аналіз допомагає обрати напрям, за яким підприємство буде розвиватися. Без стратегії у підприємства відсутній обгрунтований план діяльності і єдина програма досягнення бажаних результатів. Стратегічний аналіз зосереджується, насамперед, на вивченні ринку та дослідженні внутрішніх ресурсів і можливостей, які дозволять от- 
римати на ринку конкурентні переваги. Саме стратегічний аналіз дає відповіді на три основних питання: 1) В якому становищі перебуває підприємство зараз? 2) В якому становищі воно повинно бути через певний проміжок часу (через три, п'ять, десять років)? 3) Які існують шляхи досягнення бажаного становища і ягими способами його можна досягнути?

Стратегічний аналіз розглядаємо як наукову і практичну діяльність, навчальну дисципліну (рис. 1).

\begin{tabular}{|c|c|c|}
\hline \multicolumn{3}{|c|}{ CTPATEГTИНИЙ AHAMI3 } \\
\hline \multirow[b]{2}{*}{$\begin{array}{c}\text { Галузь } \\
\text { наукових знань }\end{array}$} & \multirow[b]{2}{*}{ Практична діяльність } & \multirow{3}{*}{ Навчальна дисципліна } \\
\hline & & \\
\hline$\downarrow$ & ПРЕДМЕТ $\$ ДОСЛЩЖЕННЯ & \\
\hline $\begin{array}{l}\text { удосконалення і } \\
\text { розвиток } \\
\text { методології } \\
\text { стратегічного } \\
\text { аналізу } \\
\end{array}$ & 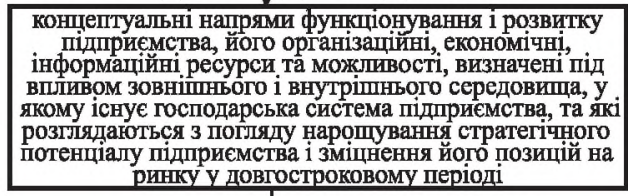 & $\begin{array}{c}\text { організація і методика } \\
\text { навчального процесу для } \\
\text { яккісного отримання знань } \\
\text { і навиків щодо процесу } \\
\text { проведення стратегічного } \\
\text { аналізу } \\
\end{array}$ \\
\hline 1 & оБ'СКТ $\backslash$ досЛцДЖЕНня & \\
\hline $\begin{array}{l}\text { порядок організації } \\
\text { та проведення } \\
\text { стратегічного } \\
\text { аналізу }\end{array}$ & $\begin{array}{l}\text { окремі стратегічні господарські підрозділи, } \\
\text { стратегічні зони господарювання, сектори } \\
\text { бізнесу або окремі продукти }\end{array}$ & $\begin{array}{c}\text { теоретицні знання та } \\
\text { практичні навики } 3 \\
\text { організащії і методики } \\
\text { стратегічного аналізу }\end{array}$ \\
\hline \multicolumn{3}{|c|}{ ОФНОВНЕ ЦЛЬОВЕ СПРЯМУВАННЯ СТРАТЕГГЧНОГО АНАЛЗУ } \\
\hline $\begin{array}{c}\text { розробка } \\
\text { теоретичних основ } \\
\text { стратегічного } \\
\text { аналізу та їх } \\
\text { постійне } \\
\text { удосконалення }\end{array}$ & \begin{tabular}{|c|} 
опис і оцінка стану господарської діяльності та \\
надання власникам підприсмства інформації \\
довгостроковогохарактеру, отриманої в результаті \\
оцінки діяльності підприємства, виявлення і \\
вимірювання невикористаних резервів \\
господарювання з метою обгрунтування прийняття \\
стратегічних управлінських рішень та формування \\
ефективної стратегіі розвитку \\
\end{tabular} & \begin{tabular}{|c} 
отримання студентами \\
теоретичних знань і \\
набуття практичних \\
навиків щодо організації та \\
методики проведення \\
стратегічного аналізу для \\
використання у практичній \\
діяльності \\
\end{tabular} \\
\hline & СУБ'ЄКТИ СТРАТЕГІЧНОГО АНАЛІЗУ & \\
\hline $\begin{array}{l}\text { дослідник } \\
\text { (аналітик) зі } \\
\text { стратегічного } \\
\text { аналізу }\end{array}$ & $\begin{array}{l}\text {-особи, які організовують стратегічний } \\
\text { аналізу; } \\
\text {-особи, які проводять стратегічний аналіз; } \\
\text { - особи, які отримують інформацію за } \\
\text { результатами аналізу - внутрішні та } \\
\text { зовніпші користувачі }\end{array}$ & $\begin{array}{l}\text { викладачі економічного } \\
\text { профілю та студенти, які } \\
\text { навчаються за } \\
\text { спеціальністю "Облік і } \\
\text { оподаткування", "Фінанси } \\
\text { і кредит", "Економіка } \\
\text { підприємства" }\end{array}$ \\
\hline
\end{tabular}

Рис. 1. Запропоноване розмежування об' сктів, предмету, завдань і суб'єктів стратегічного аналізу за трьома формами прояву

Джерело: побудовано автором

Предметом будь-якої науки прийнято вважати сферу дослідження. Стратегічний аналіз як галузь наукових знань досліджує господарську діяльність підприємства як стратегічну зону господарювання. Стратегічний аналіз - функціональна наука, основним призначенням якої є забезпечення потреб практики. Дійсна користь полягає у побудові стратегії розвитку підприємства у довгостроковій перспективі за рахунок виявлення невикористаних резервів внутрішнього та зовнішнього середовища, зокрема, збільшення обсягу реалізації продукції та підвищення ії якості, поліпшення використання економічних ресурсів, підвищення рентабельності та збільшення прибутку підприємства тощо.

Для цього стратегічний аналіз розробляє методи, які дають можливість фахівцяманалітикам сформувати варіанти стратегічних управлінських рішень та побудувати адекватну та ефективну стратегію розвитку суб'єкта господарювання з метою оцінки результатів його діяльності на найближчі 10-15 років як складової форму- 
вання суспільного благоустрою. Оскільки господарські рішення, прийняті на основі недостовірної інформації, направлені як на зовнішнє навколишне середовище, так i всередину підприємства, порушують інтереси суспільства, негативно впливають на майбутнє підприємства та ї власників. Тобто предметом стратегічного аналізу як галузі наукових знань є удосконалення і розвиток його методології.

Зміст стратегічного аналізу як практичної діяльності визначається сукупністю методів, які адекватно застосовуються для розробки та коригування стратегії за допомогою результатів стратегічних досліджень, які дозволяють:

- визначити ринкову позицію підприємства;

- $\quad$ виявити потреби споживачів для забезпечення функціонування підприємства в довгостроковій перспективі;

- $\quad$ визначити цілі розвитку та підтримки життєздатності та розвитку підприємства;

- визначити необхідні обсяги виробництва, структуру асортименту;

- налагодити ефективні зв'язки з партнерами, споживачами, громадськістю для формування позитивного іміджу;

- створити та поповнити власні бази даних і знань, які забезпечують обгрунтування стратегічних рішень, що приймаються.

Саме стратегічний аналіз може допомогти підприємству реалізувати його стратегічне бачення. Оскільки стратегічний аналіз використовує інформацію, яка характеризується високим рівнем невизначеності, його проведення вимагає глибокого системного дослідження фактів та явищ. Відповідно, предметом стратегічного аналізу є концептуальні напрями функціонування і розвитку підприємства, його організаційні, економічні, інформаційні ресурси та можливості, визначені під впливом зовнішнього (макро-) і внутрішнього (мікро-) середовища, у якому існує господарська система підприємства, та які розглядаються 3 погляду нарощування стратегічного потенціалу підприємства і зміцнення його позицій на ринку у довгостроковому періоді.

Таким чином, стратегічним аналізом є спосіб дослідження і перетворення бази даних, одержаних внаслідок аналізу середовища, на стратегію підприємства. Стратегія інтегрує багато конкурентоспроможних дій та підходів до бізнесу, від яких залежить успішність діяльності підприємства. В цілому, стратегія - це план управління підприємством, спрямований на зміцнення його позицій, задоволення потреб споживачів та досягнення передбачених цілей.

Щодо мети стратегічного аналізу, то погляди вчених є схожими. Зокрема, I.C. Левик [1] наголошує, що це формування множин альтернатив для прийняття стратегічних рішень, які забезпечать конкурентні переваги досліджуваного об'єкта та його прибутковість в довгостроковій перспективі з максимальним використанням потенціалу підприємства та змін у зовнішньому середовищі на свою користь. 3.Є. Шершньова, С.В. Оборська [8] визначають мету стратегічного аналізу як змістовний і формальний опис об' єкта дослідження, виявлення особливостей, тенденцій, можливих і неможливих напрямів його розвитку, що вважаємо досить вузьким тлумаченням за браком визначення у ньому основного призначення стратегічного аналізу - формування стратегії. В.В. Пастухова [6] та I.М. Парасій-Вергуненко [4; 5] під завданням стратегічного аналізу розуміють оцінку перспективного стану ресурсів підприємства і сегментів ринку із метою виявлення стратегічних позицій і відповідного використання ресурсів для найкращого освоєння перспективних сегментів, створення необхідної інформації для стратегічного управління. Узагальнюючи наведені позиції вчених, вважаємо необхідним уточнити та доповнити визначення цільового спрямування (мети) стратегічного аналізу: опис і оцінка стану господарської діяльності та надання власникам підприємства інформації довгострокового характеру, отриманої в результаті оцінки діяльності підприємства, виявлення і вимірювання невикористаних резервів господарювання 3 метою обгрунтування прийняття стратегічних управлінських рішень та формування ефективної стратегії розвитку.

За даних умов господарювання зростає відповідальність та зацікавленість підприємства у кінщевих результатах свого господарювання, підприємства стають не 
зацікавлені у випуску неконкурентоспроможної продукції, оскільки наслідком дотримання такої стратегії розвитку буде отримання підприємством збитків від господарської діяльності, шо у кінщевому підсумку призведе до його банкрутства. Виконання кожного із завдань стратегічного аналізу підпорядковується одній цілі - формуванню стратегії розвитку підприємства для забезпечення ефективності та безперервності його господарської діяльності.

Виходячи 3 вищенаведеного, стратегічний аналіз $є$ певною системою, яка має певний набір завдань, що між собою знаходяться в певній підпорядкованості (рис. 2).

У відповідності до теорії менеджменту “дерево цілей” є одним із засобів, що використовуються для обгрунтування нових рішень про вибір чи коригування потужності операційної системи, а також для розв'язання широкого ряду інших проблем управління операційною системою [7, с. 315]. Використання “дерева завдань" в стратегічному аналізі обгрунтовується тим, що за його допомогою визначаються всі можливі альтернативи стратегічних рішень та ураховуються всі внутрішні та зовнішні фактори і причини, що зумовили позитивні та негативні зміни у діяльності суб'єкта господарювання.

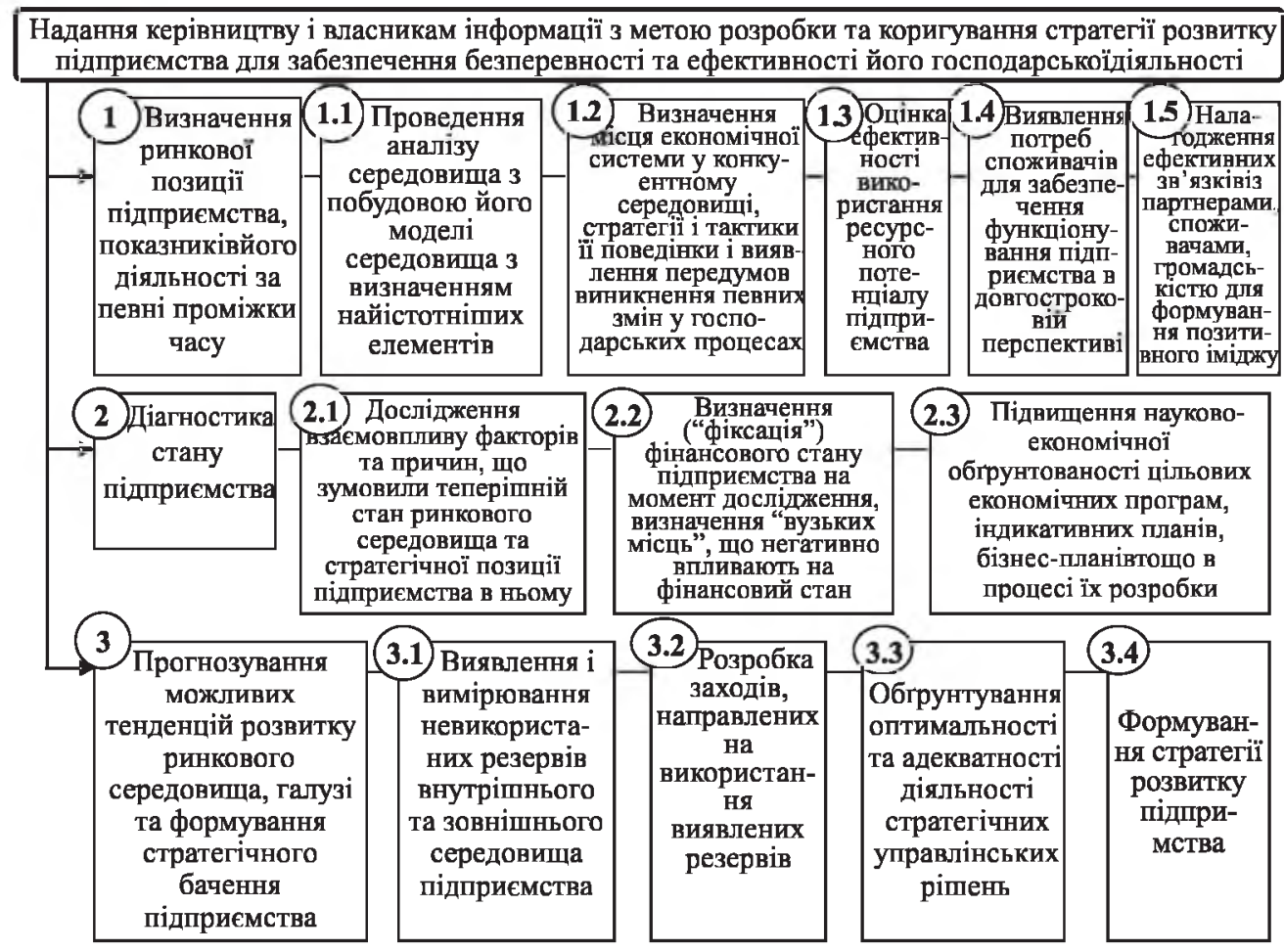

\section{Рис. 2. “Дерево завдань" стратегічного аналізу діяльності} суб'скта господаргвання: фрагментарний розріз

Джерело: побудовано автором

У точнення та доповнення завдань стратегічного аналізу (рис. 2) зумовлено характером його методики, яка носить перспективний характер, а також дає можливість удосконалення та зміни порядку його проведення відповідно до нових економічних умов.

Викладання стратегічного аналізу у вищих навчальних закладах дає можливість сформувати знання 3 методики та техніки проведення аналітичних досліджень для виявлення резервів підвишення ефективності господарської діяльності та обгрунтування стратегічних управлінських рішень, а також формування стратегії розвитку підприємства. 
Отже, стратегічний аналіз $є$ функціональною, прикладною галуззю наукових знань, що має дві складові - систему знань і систему конкретного їх використання для підготовки вихідної інформації з удосконалення стратегічного управління розвитком підприємств. Для забезпечення цього необхідна чітке групування суб' єктів стратегічного аналізу.

Якщо розглядати суб'єкта стратегічного аналізу як наукової діяльності, ним $\epsilon$ дослідник (аналітик), який займається розробкою теоретичних основ цієї галузі наукових знань. Викладання аналізу неможливе без викладачів і студентів, взаємодія яких дає можливість студентам оволодівати теоретичними основами стратегічного аналізу для використання на практиці.

У господарській діяльності підприсмства суб' єктів стратегічного аналізу поділяємо на три групи:

- особи, які організовують стратегічний аналіз - особи, які визначають економічну доцільність будь-якого організаційного, технічного або технологічного заходу (керівник (власник), головний бухгалтер);

- особи, які проводять стратегічний аналіз - аналітик-фахівець зі стратегічного аналізу, які безпосередньо висувають проекти управлінських рішень щодо розвитку підприємства у довгостроковій перспективі;

- особи, які отримують інформацію за результатами аналізу - внутрішні (власники, акціонери, керівники) і зовнішні (покупці, податкові органи, урядові органи, статистичні органи, постачальники, кредитори) користувачі.

Висновки та перспективи подалыших досліджень. Отже, з наведеного вище можна зробити наступні висновки. По-перше, роль стратегічного аналізу в системі управління підприємством визначається його перевагами, які дають змогу створити інформаційну базу для прийняття стратегічних рішень на основі оцінювання внутрішнього і зовнішнього середовиша; зменшити негативний вплив змін зовнішнього і внутрішнього середовища на результати діяльності підприємства; швидко реагувати на зміни та вносити відповідні корективи до стратегії, яка реалізується на даному етапі діяльності суб' єкта господарювання; визначити необхідний рівень потенціалу підприсмства та дію чинників зовнішнього середовиша, які в поєднанні дають змогу досягнути його стратегічних цілей. По-друге, з метою повної реалізації функцій стратегічного аналізу побудовано “дерево завдань" стратегічного аналізу діяльності суб' єкта господарювання з метою визначення порядку організації та розробки його методики для найбільш повного виконання завдань, побудови стратегії розвитку підприємства 3 метою забезпечення ефективності та безперервності його господарської діяльності. По-третє, стратегічний аналіз розглядаємо як наукову та практичну діяльність, навчальну дисципліну. Основним призначенням стратегічного аналізу як галузі наукових знань $€$ забезпечення потреб практики, тому його предметом $€$ удосконалення і розвиток методології. Практична цінність стратегічного аналізу полягає в дослідженні та перетворення інформаційної бази, одержаної внаслідок аналізу середовища, на стратегію підприємства, яка інтегрує багато конкурентоспроможних дій та підходів до бізнесу, від яких залежить успішність діяльності суб' єкта господарювання в довгостроковій перспективі. Для забезпечення достовірності отриманих даних про стан внутрішнього та зовнішнього середовища підприємства слід мати теоретичні знання і практичні навики щодо організації і методики стратегічного аналізу, що відповідає його призначенню як навчальної дисципліни.

\section{Список використаних джерел}

1. Левик I. С. Суть стратегічного аналізу, його місце та роль в системі управління підприсмством // Основи фінансового аналізу. 2009. № 3. С. 173-178.

2. Литвак Б. Г. Разработка управленческого решения: учеб. / Б. Г. Литвак. М.: Дело, 2000.392 c.

3. Маляревский В. Ю. Оценка эффективности управленческих решений // Проблемы теории и практики учета, аудита, анализа и пути их решения: материалы Всеукраинской науч.-метод. конф. Севастополь: Изд-во СевНТУ, 2003. С. 218-219. 
4. Парасій-Вергуненко I. М. Конщептуальні засади стратегічного аналізу в банках // Фінанси України. 2004. №8. С. 111-117.

5. Парасій-Вергуненко I. М. Стратегічний аналіз у банках: теорія, методологія, практика: моногр.. К.: КНЕУ, 2007. 360 с.

6. Пастухова В. В. Аналіз системи стратегічного управління підприємством: методологічний аспект // Фінанси України. 2000. № 10. С. 69-74.

7. Сумець О. М. Основи операційного менеджменту: підруч. / За ред. проф. О. Л. Яременка. К.: ВД "Професіонал", 2005. 416 с.

8. Шершньова 3. Є. Стратегічне управління: навч. посіб. К.: КНЕУ, 1999. 545 с.

\author{
И. Т. РАЙКОВСКАЯ, \\ кандидат экономических наук, \\ дочент кафедры учета и налогообложения, \\ Киевский кооперативный институт бизнеса и права
}

\title{
Стратегический анализ в системе долгосрочного управления предприятием
}

В статье проведена систематизация взглядов научных сотрудников относительно места стратегического анализа в системе управления предприятием, определены его задания на современном этапе развития экономических отномений. Установлена прямая и обратная связь стратегического анализа с функииями управления и предложено разделение объектов, предмета, заданий и субъектов стратегического анализа за тремя формами проявления как отрасли научных знаний, учебной дисциплины и практической деятельности

Ключевые слова: стратегический анализ, стратегическое управление, внеиняя среда, внутренняя среда, стратегические реиения.

I. T. RAIKOVSKA,

PhD (Economics),

associate professor, of Department of Accounting \& Taxation Kyiv Cooperative Institute of Business and Law

\section{Strategic Analysis the System of Long-term Management of Enterprise}

The article is devoted research of role of strategic analysis in management system of enterprise with parallel determination of change of him rich in content filling, objects, article, tasks and subjects, in the context of development of social-economic relations.

On the basis of analysis of economic literature certainly, that a strategic analysis is, at first, by independent direction of analytical research, that occupies a leading place on each of the stages of strategic management an enterprise and envisages rich in content description of economic subject, exposure of features, tendencies, possible and impossible directions of its development for the sake of timely and adequate reaction on changes in the environment of its functioning and forming competitive edges that in a long-term prospect will provide increase of business cost, and, secondly, informative providing, as engulfs the results of actions of all other functions of management, is based on the facts of their display, redoes and reproduces new state information and its place activity of enterprise in an external environment for the sake of construction of strategy of continuity of activity of subject of menage. Differentiating of objects, article, tasks and subjects of strategic analysis, is offered after three forms of display as areas of scientific knowledges, educational discipline and practical activity, and certainly, that basic setting of strategic analysis as areas of scientific knowledges are providing of necessities of practice, that is why its article is an improvement and development of methodology.

In accordance with the modern understanding of strategic analysis and for complete realization of his functions the "tree of tasks" of strategic analysis activity of subject of 


\section{ЕКОНОМКА ТА УПРАВЛІННЯ}

menage with a purpose determination of order of organization and development of its method, construction of strategy of development of enterprise which will allow to form strategic thought of workers and provide efficiency and continuity of him economic activity is built.

Keywords: strategic analysis, strategic management, external environment, internal environment, strategic decisions.

Посилання на статтю:

Райковська I. Т. Стратегічний аналіз в системі довгострокового управління підприємством // Науковий вісник Національної академії статистики, обліку та аудиту: зб. наук. праць. 2017. №1-2. С. 84-92. 